\title{
The influence of inhaled corticosteroids on asthma control test in smokers and non-smokers with asthma
}

\author{
Zoran Arsovski $^{1 *}$, Gorica Breshkovska ${ }^{1}$, Dejan Dokic ${ }^{1}$, Elena J. Janeva ${ }^{1}$, \\ Anita Arsovska ${ }^{2}$, Viktor Isjanovski ${ }^{3}$ \\ ${ }^{1}$ University Clinic of Pulmonology and Allergology, Medical Faculty, University Ss Cyril and Methodius, Skopje, \\ Majka Tereza, 17, 1000 Skopje, R. Macedonia \\ ${ }^{2}$ University Clinic of Neurology, Medical Faculty, University Ss Cyril and Methodius, \\ Majka Tereza, 17, 1000 Skopje, R. Macedonia \\ ${ }^{3}$ Psychiatric Hospital Skopje, Medical Faculty, University Ss Cyril and Methodius, \\ Proleterska bb, 1000 Skopje, R. Macedonia
}

Received: October 2016; Accepted: December 2016

\begin{abstract}
Smoking in asthmatics is responsible for the worsening of asthma symptoms, more frequent asthma exacerbations and hospitalizations and lowered quality of life. In smoking asthmatics the designated doses of the inhaled corticosteroid treatment are usually insufficient to accomplish total asthma control.

Out of 54 screened adult patients up to 50 years old with mild asthma, 38 were involved in the study. They were divided in two groups: smokers and non-smokers. They received a total daily dosage of $500 \mu \mathrm{g}$ of inhaled fluticasone propionate. A rescue medication, a short-acting B2 agonist (salbutamol) in a dosage of $0.1 \mathrm{mg} /$ per inhaled dose, was used when needed. Asthma was diagnosed by a positive metacholine provocation test and/or a positive bronchodilatator response.

An asthma control test i.e. the ACT-TM questionnaire was performed before the beginning of the study and 6 weeks after the treatment with fluticasone propionate of the previous corticosteroid-naive patients. A statistically positive response $(p<0.05)$ was reached in favor of non-smoking asthmatics.

It can be concluded that ACT is a reliable tool to assess the effect of the topical corticosteroid treatment in non-smoking and smoking asthmatics. An achievement of better asthma control could be expected among both of the examined groups, but the effect of the intervention in the therapy is estimated to be more expressed within the group of asthmatic non-smokers.

In smoking asthmatics there is a need for other therapeutic modalities such as increasing the dosage of inhaled corticosteroids, usage of combination therapy and/or adding low doses of aminophylline.
\end{abstract}

Key words: asthma, fluticasone propionate, asthma control test

\section{Introduction}

The prevalence of smokers in the USA is $16.7 \%$ among men and $13.6 \%$ among women (CDC, USA, 2015). In the past, the prevalence rates of smoking in asthmatics were similar to those of non-asthmatics. Thankfully, in recent years data shows that smoking was less frequent among asthmatics than general population ( 26 vs. $31 \%$ ) (Cerveri et al., 2012). Still, there is a higher incidence of smokers with asthma among adolescents and asthmatics living in developing countries. These groups are more frequently treated by the Units for emergency medical assistance

*arso66@yahoo.com 
(Emergency departments), up to 35\% (Kauppi et al., 2014).

It is well known that the exposure to tobacco smoke can cause bronchoconstriction and acute asthma attack, worsening of asthma symptoms and decline in FEV1, more frequent asthma exacerbations, more frequent hospitalizations, lowered quality of life, as well as altered or insufficient therapeutic response to the standard therapy, envisaged in the global guidelines for asthma treatment around the world (Thomson et al., 2005; Thomson et al. 2013).

Tobacco smoke has an effect on the immune system, modifying the inflammation associated with asthma; it causes oxidative stress, changes in the remodeling of the respiratory airways and possible emphasis of the allergenic sensitivity. Modified inflammation among smokers with asthma is not very investigated, because most of the studies for asthmatics on which the effects of anti-inflammatory therapy are followed are executed on a group of examinees with asthma that are non-smokers. A cause for this phenomenon could be a possible corticosteroid resistance among smokers with asthma, but the reason for this is still insufficiently researched. It is assumed that the altered response to corticosteroids may be a consequence of an altered cellular inflammatory response (increased neutrophils or decreased eosinophils), changes in the relation of $\alpha$ and $\beta$ corticosteroid receptors (increased expression of the glucocorticoid receptor $\beta$ ), increased activation of proinflammatory transcription factors $(\mathrm{NF} \kappa \mathrm{B})$ or reduced activity of histone deacetylase. The altered therapeutic response is particularly noticeable towards inhaled corticosteroid therapy. The anticipated doses are insufficient for achieving full asthma control within smoking asthmatics and there is an inadequate improvement of the respiratory function.

In literature there is a suggestion for an alternative and maybe only rational approach in favor of renewing the corticosteroid sensitivity with low doses of theophylline (Braganza et al., 2008; Barns 2003), using its anti-inflammatory potential. It is considered that small doses of theophylline products have anti-inflammatory and immunomodulatory effects on asthma and on chronic obstructive pulmonary disease (COPD) (Cosio et al. 2009; Spearset al., 2009). The low plasma concentrations of theophylline (5$10 \mathrm{mg} / \mathrm{L}$ ) have an anti-inflammatory effect on asthma and COPD, but do not have a bronchodilatatory effect (Barns 2003). According to Shah et al. and Wang et al. and their coworkers, giving ICS and slowly released theophylline has the same effect as applying a double dose of ICS and that has been proven through asthma control, the symptoms and the respiratory function (Shah et al., 2003; Wang et al. 2005). The latest scientific insights on the effect of smoking on asthma confirm the existence of the altered therapeutic response among this specific phenotype of asthmatics and they initiate new studies which would provide better methods of treatment (Polosa et al., 2013).

Because of all of these facts it is very important to evaluate whether there is any significant influence of the usage of inhaled corticosteroids in smokers and non-smokers with asthma on the tests which evaluate asthma control.

The aim of the study was to evaluate the influence of inhaled corticosteroids on asthma control test (ACT) among smokers and nonsmokers with mild asthma. Objectives of the study was to determinate the improvement of ACT during the standard regiment of average therapeutic doses of fluticasone propionate in patients with mild asthma (smokers and nonsmokers).

\section{Design of the study}

In a randomized, parallel study an investigation was done among 38 adult asthmatics up to 50 years old with mild asthma. Asthma was previously diagnosed with standard tests according to Global Initiative For Asthma (GINA) guidelines. The patients were randomized in two groups according to gender, age and starting forced expiratory volume in 1 second (FEV1), a group of smokers and a group of non-smokers, among which the therapeutic response to inhaled fluticasone propionate was determined. Non-smokers were considered persons who have never smoked, or have been smoking only for two years during their whole life, or stopped smoking at least one year before the examination. Smokers were considered those who smoked 10-40 cigarettes per day or had a smoking history of 2 to 15 years, but without diagnosis of COPD.To distinct the possible connection to Asthma/COPD Overlap Syndrom (ACOS), patients that smoked more than 40 cigarettes per day or patients that have been smoking for more than 15 years have not been included in the study.

\section{Methods}

At the beginning of the research, demographic information, information about the beginning and the duration of the asthma, symptoms of the disease, past diseases, family, social and pharmacological anamnesis were obtained from the history of the patient. All the smoking patients were advised to stop smoking, but those who refused were included in the study as asthmatic smokers.

In all patients the spirometry was performed using a Power-Cube spirometer.The therapeutic response to inhaled fluticasone propionate was determined among patients before and after 6 weeks of treatment on previously steroid-naive patients using the asthma control test (ACTTM) questionnaire (Asthma Control Test). They received a dose of $250 \mu \mathrm{g}$ twice daily (total daily dose of $500 \mu \mathrm{g}$ ). As a facilitator drug, a short-acting $\beta 2$ agonist - bronchodilator, salbutamol from $0.1 \mathrm{mg}$, per inhaled dose, was used by need. ACT-TM score between 5-19 means poor control of asthma and between 20 - 25 means well controlled asthma.

For statistical analysis descriptive methods, a method with mean value, standard deviation, Mann-Whitney test and confidence interval of $95 \%(\mathrm{p}<0.05)$ were used. 


\section{Results}

Out of 54 screened patients with asthma, 38 were involved in the research (Fig 1). The patients were divided in two groups: smokers and non-smokers with asthma.

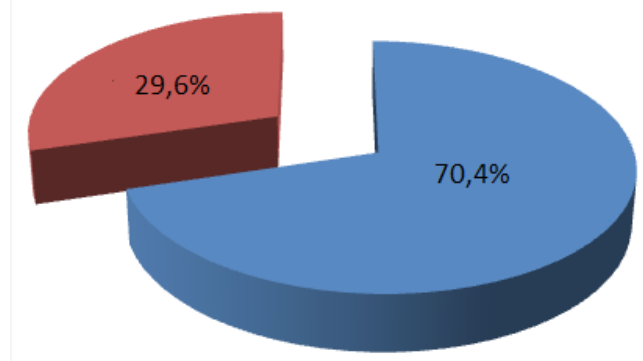

- included not included

Fig. 1. Percentage of included and excluded patients.

There was no significant difference obtained between the two groups according to the duration of the asthma before the examination. (Table 1, Fig.2). There was not a statistically significant difference in ACT score in smokers and nonsmokers before the examination (Table 2; Fig. 3). .

A statistically positive response $(\mathrm{p}<0.05)$ was obtained with a comparative analysis among the ACT values after 6

Table 1. Duration of mild asthma in smokers and nonsmokers

\begin{tabular}{|c|c|c|c|c|}
\hline Mean & Mean & Valid N Valid N & Std. Dev. & Std. Dev. \\
\hline 6.454545 & 6.312500 & 16 & 2.939506 & 3.458685 \\
\hline
\end{tabular}

Mean \% - mean value expressed in percentage of predicted values, SD \% - standard deviation expressed in percentage of predicted values, MannWhitney $\mathrm{U}$ test $(\mathrm{p}=0.8485)$

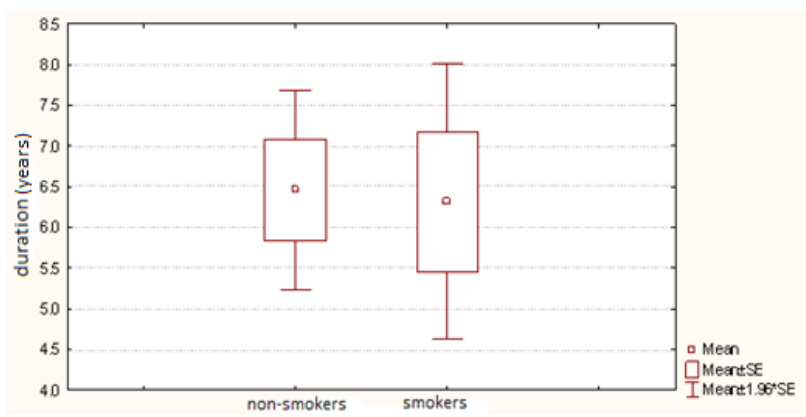

Fig. 2. Asthma presence before the examination. weeks of treatment among the two examined groups of patients (Table 3; Fig. 4).

The test for asthma control was worse among asthmatic smokers.

Asthma control test - ACT is a simple tool to assess the asthma control in non-smoking and smoking asthmatics (Gurkova et al., 2015). Smoking is associated with poor asthma control (Haughney et al. 2008; McLeish et al., 2010). In our study we also found that the ACT score was worse in smoking asthmatics compared to non-smoking asthmatics before the beginning of the inhaled corticosteroid treatment. Another big prospective study on asthma control which was performed in 56 pulmonology centers in Italy proved that one of the main reasons for lack of asthma control, despite poor adherence to therapy and comorbidities, was exposure to smoking (Terzano et al., 2012). After 6 weeks of treatment with an inhaled corticosteroid we found weak but statistically significant improvement of ACT in both groups of patients although there are findings in literature that asthmatic smokers are less responsive to inhaled corticosteroid therapy (Thomson et al., 2009). Improvement in ACT score was bigger in non-smoking asthmatics. Novel therapies could improve the outcome in asthma control i.e. combined treatment especially with extra-fine formulations of inhaled corticosteroids and long acting beta 2 agonists could improve asthma control and pulmonary function among former and current smokers with asthma (Brusselle et al., 2012). Second-line treatments for asthma also could improve the ACT score (Wang et al., 2015).

Table 2. ACT score in smokers and nonsmokers before the examination

\begin{tabular}{|c|c|c|c|c|c|}
\hline Mean & Mean & Valid N & J Valid N & N Std. Dev. & Std. Dev. \\
\hline 18.63636 & 17.50000 & 22 & 16 & 2.300009 & 1.966384 \\
\hline
\end{tabular}

$\mathrm{ACT}$ value- mean $\%$ - mean value expressed in percentage of predicted values, $\mathrm{SD} \%$ - standard deviation expressed in percentage of predicted values, Mann-Whitney U test $(\mathrm{p}=0.1334)$

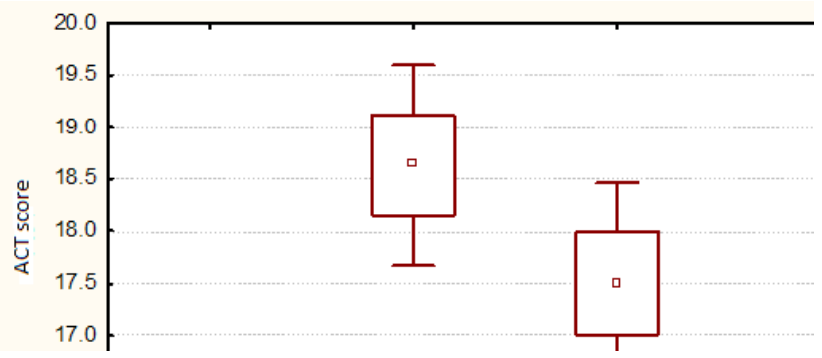

Fig. 3. ACT score before the examination. 
Table 3. ACT values in smokers and nonsmokers after 6 weeks of therapy

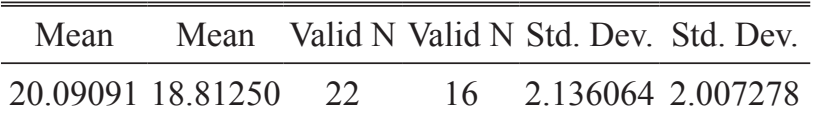

ACT value- mean $\%$ - mean value expressed in percentage of predicted values, $\mathrm{SD} \%$ - standard deviation expressed in percentage of predicted values, Mann-Whitney U test ( $\mathrm{p}=0.0426)$

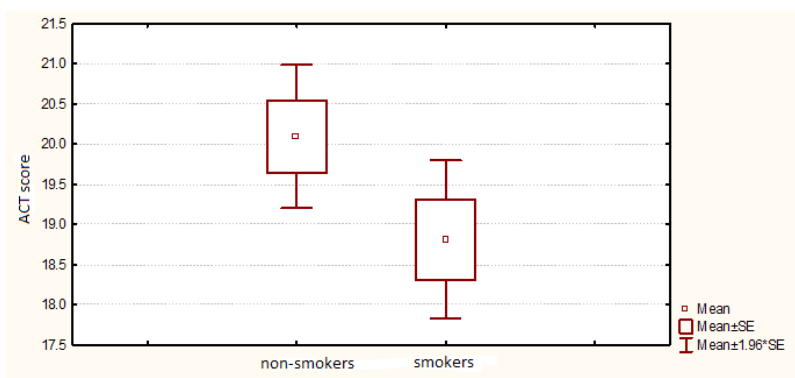

Fig. 4. ACT after 6 weeks of therapy.

There is a need for a larger randomized parallel study among asthmatic smokers and non-smokers, a one that would study the symptom score, the number of night awakenings due to asthma, the frequency of exacerbations of asthma and the use of facilitator drugs in order to completely define the altered therapeutic response towards inhaled corticosteroids among asthmatic smokers. Parallel to that other factors could influence the asthma control, not defined only by ACT, such as the eventual connection of the years of smoking (pack years) to the level of the lung function, the level of nicotine addiction among the asthmatic smokers, the presence of atopy to inhalational allergens and concomitant diseases among smokers and nonsmokers with asthma.

\section{Conclusion}

ACT is a reliable tool to assess the effect of the topical corticosteroid treatment in non-smoking and smoking asthmatics. An achievement of better asthma control could be expected among both of the examined groups, but the effect of the intervention in the therapy is estimated to be more expressed within the group of asthmatic non-smokers.

\section{References}

Asthma Control Test - TM. http://www.asthma.com/additionalresources/asthma-control-test.html.

Barns, P.J., 2003. Theophylline: new perspectives on an old drug. Am. J. Resir.Crit.Care Med. 167:813-818

Braganza, G., Chaudhuri, R., Thomson, N.C., 2008. Treating patients with respiratory disease who smoke. Ther.Adv. Respir. Dis. 2(2):95-107.

Brusselle, G., Peché, R., Van den Brande, P., Verhulst, A., Hollanders, W., Bruhwyler, J., 2012. Real-life effectiveness of extrafine beclomethasone dipropionate/formoterol in adults with persistent asthma according to smoking status. Respir. Med. 106 (6):811-819.

Centers for Disease Control and Prevention, (CDC). Current cigarette smoking among adults in the United States 2015.

https://www.cdc.gov/tobacco/data_statistics/fact_sheets/adult_ data/cig_smoking/index.htm

Cerveri, I., Cazzoletti, L., Corsico, A.G., Marcon, A., Niniano, R., Grosso, A., Ronzoni, V., Accordini, S., Janson, C., Pin, I., Siroux, V., de Marco, R., 2012. The impact of cigarette smoking on asthma: a population-based International cohort study. Int. Arch. Allergy. Immunol. 158(2):175-183.

Cosio, B.G., Soriano, J.B.(2009). Theophylline again? Reasons for believing. Eur.Respir. J.34(1):5-6.

Gurkova, E., Poplekova, P., 2015. Validity of asthma control test in assessing asthma control in Czech outpatient setting. Cent. Eur. J. Publ. Health. 23 (4):286-291.

Haughney, J., Price, D., Kaplan, A., Chrystyn, H., Horne, R., May, N., Moffat, M., Versnel, J., Shanahan, E.R., Hillyer, E.V., Tunsäter, A., Bjermer, L., 2008. Achieving asthma control in practice: understanding the reasons for poor control. Respir. Med. 102:1681-1693.

Kauppi, P., Kupiainen, H., Lindqvist, A., Haahtela, T., Laitinen, T., 2014. Long-term smoking increases the need for acute care among asthma patients: a case control study. B.M.C. Pulmonary Medicine.14:119.

McLeish, A.C., Zvolensky, M.J., 2010. Asthma and Cigarette smoking: a review of empirical literature. J. Asthma. 47:345361.

Polosa, R., Thomson, N.C., 2013. Smoking and asthma: dangerous liaisons. Eur.Resp. J.41:716-726.

Shah, L., Wilson, A.J., Gibson, P.G., Coughlan, J., 2003. Long acting beta-agonists versus teophylline for maintenance treatment of asthma (Cochrane review). Cochrane database. Syst.Rev.Issue. (3):CD001281.

Wang, K., Tian, P., Fan, Y., Wang, Y., Liu, C., 2015. Assessment of second-line treatments for patients with uncontrolled moderate asthma. Int. J.Clin.Exp.Med. 8:19476-19480. 


\title{
Резиме
}

\section{Влијанието на инхалаторните кортикостероиди на тестот за контрола на астмата кај пушачи и непушачи со астма}

\author{
Зоран Арсовски ${ }^{1 *}$, Горица Брешковска ${ }^{1}$, Дејан Докиќ ${ }^{1}$, Елена Ј. Јанева ${ }^{1}$, \\ Анита Арсовска², Виктор Исјановски

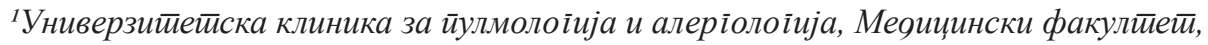 \\ Универзииеети Св. Кирил и Метиояиј, Скойје, Мајка Тереза, 17, 1000 Скойје, Р. Макеоонија \\ ${ }^{2}$ Униерзииееискка клиника за невролоіија, Меяицински факулиети, Универзииеей Св. Кирил и Мейояиј, Скойје, \\ Мајка Тереза, 17, 1000 Скойје, Р. Макеяонија

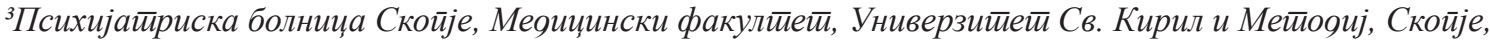 \\ Пролетерска бб,1000 Скойје, Р. Макеяонија
}

Клучни зборови: астма, fluticasone propionate, тест за контрола на астмата

Пушењето кај астматичарите ги влошува симптомите на астмата, ги зачестува егзацербациите и хоспитализациите и го намалува квалитетот на живот. Кај пушачите со астма, соодветните дози на третман со инхалаторни кортикостероиди вообичаено се недоволни за постигнување на тотална контрола на астмата.

Од вкупно 54 скринирани пациенти до 50 годишна возраст со лесна астма, 38 биле вклучени во студијата и поделени во две групи: пушачи и непушачи.Тие примиле вкупна дневна доза на $500 \mu \mathrm{g}$ инхалиран fluticasone propionate. Како лек за итна помош, по потреба, бил користен кратко делувачки 32 агонист (salbutamol) во доза од $0.1 \mathrm{mg} /$ во една инхалација. Астмата била дијагностицирана со позитивен провокациски тест со метахолин и/или позитивен бронходилататорен одговор.

Тестот за одредување на контрола на астмата, т.е. АСТ-ТМ прашалникот, беше спроведен на почеток на студијата и по 6 недели од третманот co fluticasone propionate кај пациенти кои претходно не биле на терапија со кортикостероиди. Добиен е статистички позитивен одговор за АСТ-ТМ (p<0.05) во полза на астматичарите непушачи.

Се заклучува дека тестот за одредување на контрола на астмата е сигурна алатка за да се одреди ефектот од терапијата со тописки кортикостероиди кај пушачи и непушачи со астма. Подобра контрола на астмата може да се очекува во двете испитувани групи, но ефектот од интервенцијата во терапијата се проценува дека е поизразен во групата на непушачи со астма.

Кај пушачите со астма постои потреба за други тераписки модалитети како што се: зголемување на дозата на инхалаторни кортикостероиди, користење на комбинирана терапија и/или додавање на ниски дози на аминофилин. 
